\title{
Urban access and government subsidies impact livelihood and food transition in slave-remnant communities in the Brazilian Cerrado
}

\author{
Rodrigo de Jesus Silva ${ }^{1}$ (D) Maria Elisa de Paula Eduardo Garavello ${ }^{2} \cdot$ Gabriela Bielefeld Nardoto $^{3}$. \\ Edmar Antônio Mazzi ${ }^{4} \cdot$ Luiz Antonio Martinelli $^{4}$
}

Accepted: 5 March 2019 / Published online: 28 March 2019

(C) INRA and Springer-Verlag France SAS, part of Springer Nature 2019

\begin{abstract}
The livelihood and food of rural communities is changing, possibly due to greater access to urban areas and their market economy. However, the degree of change and the main influencing factors appear to vary considerably. To characterize this process in a continuum of slave-remnant villages (Kalunga) in the Brazilian Cerrado, we assessed (i) the main influencing factors of this shift in food patterns and (ii) the isotopic composition $\left(\delta^{13} \mathrm{C}\right.$ and $\left.\delta^{15} \mathrm{~N}\right)$ in the fingernails of inhabitants. The stable isotope ratios from the fingernails of 87 volunteers from different Kalunga villages were used to determine the source and trophic chain diversity of food. In addition, we conducted semi-structured questionnaire interviews in 81 domestic units to verify details about food patterns, use of resources, and socioeconomic conditions. Data from the questionnaires were analyzed using a multinomial logistic regression to determine the relative influence of multiple factors on the transition process. From this, access to town and government subsidies was significantly associated with the reduction of subsistence farming and the consumption of staple foods like rice and beans. We also verified a gradual food change from $\mathrm{C}_{3}$ (more natural) to $\mathrm{C}_{4}$ (more processed) sources of food containing a smaller diversity items with an increase of $\delta^{13} \mathrm{C}$ and decrease of $\delta^{15} \mathrm{~N}$ toward the town. These results primarily indicate a transition pattern from locally produced foods to processed items that increases with greater urban access and more government subsidies in rural settings. This is the first time that an interdisciplinary approach with stable isotopes and one multinomial discriminant model has been used to assess the impacts of public policy and socioeconomic development on the livelihood of slave-remnant communities. The main issue raised here concerns the maintenance of food sovereignty in rural areas for residents who essentially live by their own efforts and livelihoods.
\end{abstract}

Keywords Stable isotopes $\cdot$ Development $\cdot$ Rural communities $\cdot$ Public policy $\cdot$ Farming

Rodrigo de Jesus Silva

rodrigojsilva7@gmail.com

1 Universidade Federal Rural da Amazônia (UFRA), Açaizal, Tomé-Açu, PA 69920-900, Brazil

2 Escola Superior de Agricultura "Luiz de Queiroz" (ESALQ), Departamento de Economia, Administração e Sociologia, Universidade de São Paulo (USP), Campus de Piracicaba-SP, Av. Pádua Dias, Piracicaba, SP 13418900, Brazil

3 Departamento de Ecologia, Instituto de Ciências Biológicas, Universidade de Brasília (UnB), Campus Universitário Darcy Ribeiro, Asa Norte, Brasília, DF 70910900, Brazil

4 Centro de Energia Nuclear na Agricultura (CENA), Departamento de Ecologia Isotópica, Universidade de São Paulo (USP), Campus de Piracicaba, Av. Centenário 303, Piracicaba, SP 13416-000, Brazil

\section{Introduction}

One of the consequences of globalization is the homogenization of food habits, also known as nutritional transition (Popkin 2006). It has been linked to a rise in chronic diseases pertaining to diet, including coronary disease, diabetes, stroke, and cancer (Popkin 2006). In traditional rural communities, this transition can result in a macro-transformation pattern of food habits and subsistence production (Piperata et al. 2011; Nardoto et al. 2011).

Most of the studies on food transition in rural Brazilian communities have been conducted in the Amazon region, reporting a gradual increase in the replacement of local items such as manioc and fish with processed foods due to food market accessibility (Murrieta and Dufour 2004; Nardoto et al. 2011; Piperata et al. 2011). However, there are still few studies outside the Amazon region involving the effects of 
food transition at the traditional rural community level (Rodrigues et al. 2016).

The Kalunga people are slave-remnant communities living in the Brazilian Cerrado, more precisely in the northeast region of the state of Goiás. These communities date to colonial Brazil, when the geographic isolation of both runaway and freed slaves enabled the survival and preservation of some African traditions and customs (Baiocchi 2006). The limited access to local market economies requires Kalungas from remote villages to travel for several days on foot, horseback, or on chartered trails in bad conditions to buy and sell their sparse production, mainly manioc or cassava flour (Baiocchi 2006).

The Brazilian Cerrado is one of Earth's biologically richest and most endangered biomes in the world; its original area was 2 million $\mathrm{km}^{2}$; today, it has been reduced to less than 1 million $\mathrm{km}^{2}$ mainly due to agricultural expansion (Mittermeier et al. 2004). There is a marked dry season of at least 6 months, and the mean annual precipitation is around $1200 \mathrm{~mm}$. These features are in sharp contrast with the Amazon, a region dominated by rainforests and covered by a large river network with a higher mean annual precipitation. Most of the studies on food transition in this region were conducted in Caboclos communities, which mainly contain descendants of migrants from the northeastern region of Brazil who arrived in the area in several migratory waves (Piperata et al. 2011; Nardoto et al. 2011; Schor and Azenha 2017). Consequently, due to differences in habitat, origin, and culture between Caboclos and Kalungas, findings regarding food transition in the Amazon region are not necessarily true in the Kalunga communities of the Cerrado.

The main objective of this study, therefore, was to investigate the food transition in Kalunga communities of the Brazilian Cerrado. We were especially interested in investigating not only food habits and the use of natural resources among communities but also how food market accessibility drives the food transition process in this region. We used two approaches in this study. First, the carbon and nitrogen stable isotopes in fingernails were used to infer types of foods consumed by the communities, and second, details on food items and livelihood were assessed conducting semi-structured questionnaires. Given that market access and urbanization have been increasingly prevalent in rural Brazil, we hypothesized that there would be significant differences in food habits and resource use between communities with more accessibility to food markets and remote communities with less access to these markets.

Variations in the carbon isotope composition of foods (expressed as $\delta^{13} \mathrm{C}$ ) mainly result from differences in the $\mathrm{C}_{3}$ and $\mathrm{C}_{4}$ photosynthesis pathways of plants (Farquhar et al. 1989). The $\delta^{13} \mathrm{C}$ values range from -24 to $-38 \%$ in $\mathrm{C}_{3}$ plants, while values in $\mathrm{C}_{4}$ plants range from -11 to $-15 \%$ o (Farquhar et al. 1989). Although most plants follow the $C_{3}$ photosynthetic type, a few $\mathrm{C}_{4}$ plants (e.g., maize, sugarcane, and tropical grasses) make a disproportionally high contribution to human diets, since maize is the stable diet of poultry and pork, and foraged tropical grasses are the staple diet of cattle (Nardoto et al. 2011). Besides, sugar from sugarcane is mostly present in highly processed foods like sodas, candies, biscuits, cakes, etc. (Nardoto et al. 2006).

Nutritional surveys in rural isolated communities have highlighted the importance of local products such as cassava (Manihot esculenta) and the high consumption of fish or game as sources of protein and energy (Carneiro 2003; Murrieta and Dufour 2004; Padoch et al. 2008). Manioc is a $C_{3}$ photosynthetic plant type with $\delta^{13} \mathrm{C}$ varying from -25 to $-29 \%$ o (Nardoto et al. 2011). The most significant carbon sources for game and freshwater fish have $\mathrm{a}_{3}$-like origin, since these involve items like phyto-zooplankton, leaves, fruits, seeds, and other plant debris, or other fish and animals that also have a $_{3}$-based diet (Oliveira et al. 2006; Nardoto et al. 2011).

There is an increase of approximately $3 \%$ of $\delta^{15} \mathrm{~N}$ values at each step of the food chain (Lee-Thorp and Sponheimer 2006). Therefore, the $\delta^{15} \mathrm{~N}$ value mainly indicates the consumption level of animal proteins, and the type of animal consumed (Huelsemann et al. 2009). Consequently, in more remote communities in which food habits greatly rely on game meat, manioc flour, and freshwater fish, isotopic values are expected to reveal $\mathrm{C}_{3}$-based food items coupled with higher $\delta^{15} \mathrm{~N}$ values. On the contrary, in less remote communities, access to food markets tends to increase the consumption of processed foods loaded with $\mathrm{C}_{4}$ plants, increasing the $\delta^{13} \mathrm{C}$ in consumer's tissues and decreasing their $\delta^{15} \mathrm{~N}$ values, since poultry and derivatives tend to have lower $\delta^{15} \mathrm{~N}$ values than game or wild freshwater fish (Nardoto et al. 2011). The analysis of questionnaires on food consumption were used to fine-tune the findings based on stable isotopes, since it is not possible to detect whether a high consumer $\delta^{15} \mathrm{~N}$ value was caused by the consumption of game or wild freshwater fish, nor whether a low $\delta^{13} \mathrm{C}$ value would be due to rice, pasta, or cassava consumption.

Hence, this interdisciplinary study intends to contribute to the evaluation of the factors influencing the food transition process and to carry out the isotopic mapping of the local diet to verify the extent of change in rural communities' livelihoods. Through the analysis of questionnaires using multivariate discrimination statistical models and the use of biophysical tools, this study also proposes an alternative methodology for analyzing public policies on subsidies based on the results of local opinion surveys. Stable isotopes are variations of a chemical element that have different atomic masses, and when incorporated into bodily tissues, they can be examined to infer the types of foods that were consumed (Farquhar et al. 1989). However, stable isotopes do not provide details about individual food items. In this study, these details were assessed through the questionnaires conducted in the Kalunga slaveremnant communities located in the northeast of Goiás. 


\section{Materials and methods}

\subsection{Field area and sampling}

This study surveyed 81 domestic units (UDs) distributed among 11 communities and was conducted with at least one adult (i.e., $\geq 18$ years of age) of each UD. This represents about $10 \%$ of total households in the area (Baiocchi 2006). UDs were randomly chosen according to interview availability and whether the residence was inhabited (Fig. 1). Individuals were surveyed regarding their daily food preferences and their use of natural resources (e.g., soil management, gaming, fishing, and extractivism of vegetal and animal products). A total of 35 men $(43 \%)$ and 46 women (57\%) were interviewed. Eleven communities are equivalent to $22 \%$ of the 48 officially identified communities throughout the Kalunga territory (Baiocchi 2006). The selection of these 11 villages focused on three municipalities through which the Kalunga territory extends (i.e., Monte Alegre, Teresina, and Cavalcante) in an effort to obtain a representative sample, both numerically and spatially, and to ensure a sufficient isolation gradient to minimize the effect of pseudoreplication and data spatial autocorrelation.

The tiny Kalunga villages are composed of a small number of houses that usually contain 90-100 inhabitants. They are dispersed among the valleys of the Muleque, Almas, and Contenda rivers - an area of approximately 257,000 ha. These areas are situated in the Cerrado biome, which contains the microregion of the Chapada dos Veadeiros in central Brazil. The phyto-physiognomy of this area is basically composed of cerrado rupestre (rocky vegetation) (Baiocchi 2006).

Selected communities were categorized according to whether they were more or less accessible by measuring the distance between their houses and the nearest town and determining whether there was rural public transport available. In the "more accessible" group of interviewees, 11 were in
Monte Alegre, 35 in Teresina de Goiás, and 8 in Cavalcante; in the "remote" group of interviewees, there were 10 in Monte Alegre and 17 in Cavalcante. Although this study's goal was to sample as many residents of each community as possible, some places did not fall into our criteria due to a lack of adults ( $>18$ years old) in all households. The interview script followed the same basic questions as those from studies by Nardoto et al. (2011) and was applied in a single instance over 30 days with the exception of Sundays.

\subsection{Data collection and analysis}

Information on food consumption, self-subsistence agriculture or farming, hunting and gathering, as well as demographic and socioeconomic conditions were obtained through semistructured questionnaire interviews with both closed and open-ended questions (Nardoto et al. 2011; Gragnani et al. 2013). We also recorded items that often comprised the local food of inhabitants by using a list of commonly consumed foods in Brazil. Finally, we collected fingernail samples from each interviewee for isotopic analysis.

The semi-structured interviews were applied in a standard way (without replication). This was primarily due to the difficulty of accessing certain areas, such as the remote Chapada dos Veadeiros, in addition to limited financial resources. In this regard, the method bias was overcome through the isotopic composition analysis of subjects' fingernails, which reflected their dietary habits over a 4- to 6-month period (O'Connell et al. 2001). Food characterization among Kalunga communities was mainly focused on assessing multiple factors associated with changes in the agro-food system. This study aimed to determine (1) the main factors influencing the agro-food system and (2) the isotopic signal of local foods as assessed by fingernail samples collected from community inhabitants.
Fig. 1 A typical Kalunga dwelling with adobe (mud brick) house and surrounding subsistence farming area (backyard) in Volta do Canto, Cavalcante. Mr. Casemiro is visible in the center

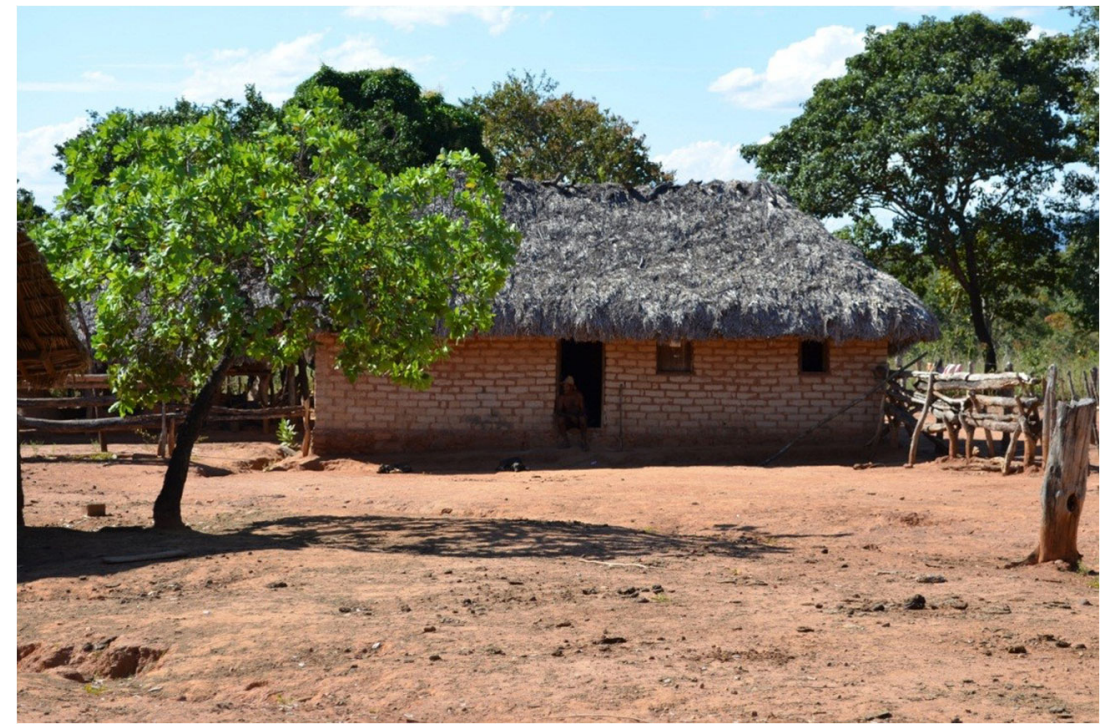




\subsection{Isotopic characterization of local food pattern}

Natural ${ }^{13} \mathrm{C}:{ }^{12} \mathrm{C}$ and ${ }^{15} \mathrm{~N}:{ }^{14} \mathrm{~N}$ isotope ratios were determined in fingernail samples collected from inhabitants of Kalunga communities. Fingernails from 86 subjects were collected, 30 from remote communities, and 56 from more accessible communities. As a control group, fingernails from 40 individuals living in the municipality of Alto Paraiso de Goiás were also sampled. This town is located in the Chapada dos Veadeiros and has approximately 7500 inhabitants.

Fingernail samples were washed with distilled water in a chloroform/methanol solution $(2: 1)$ and were cut into between one and four sections depending on the sample size, then weighed (1-2 mg) in small aluminum capsules before being subjected to isotopic analyses for carbon and nitrogen at the Isotopic Ecology Laboratory, Center for Nuclear Energy in Agriculture, University of São Paulo. The isotopic composition of carbon and nitrogen in these samples was determined through a Delta Plus mass spectrometer for isotopic ratios (Finnigan MAT) that was coupled with an elemental analyzer (Carla Erba model 1110) (Nardoto et al. 2011).

Since the ratios of ${ }^{13} \mathrm{C}:{ }^{12} \mathrm{C}$ and ${ }^{15} \mathrm{~N}:{ }^{14} \mathrm{~N}$ are very small, they are presented as a deviation from a standard and them multiplied by $1000(\%)$ according to the following equation:

$\delta=($ Rsample $/$ Rstandard -1$) \times 1000$

where $\mathrm{R}$ is the ratio between the rare and most abundant isotopes (i.e., ${ }^{13} \mathrm{C} /{ }^{12} \mathrm{C}$ and ${ }^{15} \mathrm{~N} /{ }^{14} \mathrm{~N}$, respectively) of the fingernail samples and the international standard used (i.e., Vienna PeeDee Belamnite, or VPDB, for carbon, and atmospheric air for nitrogen). We then used the isotopic dilution equation (Fry 2006) to estimate the relative proportion of $\mathrm{C}_{3}$ and $\mathrm{C}_{4}$ plants in $\delta^{13} \mathrm{C}$ fingernails using the following equation:

$\mathrm{C}_{3}=\left(\delta^{13} \mathrm{C}_{\text {fingemail }}-\delta^{13} \mathrm{C}_{\mathrm{C} 4}\right) /\left(\delta^{13} \mathrm{C}_{\mathrm{C} 3}-\delta^{13} \mathrm{C}_{\mathrm{C} 4}\right) \times 100$

where $\mathrm{C}_{3}$ is the proportion of $\mathrm{C}_{3}$-based food in the fingernail (expressed in \%), $\delta^{13} \mathrm{C}_{\text {fingernail }}$ is the $\delta^{13} \mathrm{C}$ of the fingernail sample, $\delta^{13} \mathrm{C}_{\mathrm{C} 3}$ is the mean isotopic composition of $\mathrm{C}_{3}$-based foods, and $\delta^{13} \mathrm{C}_{\mathrm{C} 4}$ is the mean isotopic composition of $\mathrm{C}_{4}$-based foods. Based on a similar survey involving several food items in Brazil, we assumed the value of $-26.1 \%$ for $\delta^{13} \mathrm{C}_{\mathrm{C} 3}$, and the value of $-11.2 \%$ for $\delta^{13} \mathrm{C}_{\mathrm{C} 4}$ (Nardoto et al. 2006, 2011).

\subsection{Statistical analysis}

Assumptions of normality and homogeneity of variances were verified through both residual analysis, and the Shapiro-Wilk and Bartlett tests of the residues, respectively. The differences between treatments - i.e., the control group (Alto Paraíso fingernails) and fingernails from remote or more accessible communities - were verified through a one-way analysis of variance (ANOVA) of the $\delta^{15} \mathrm{~N}$ and $\delta^{13} \mathrm{C}$ values.
Subsequently, a post hoc Tukey's test for multiple comparisons was applied to both groups. Notably, the isotopic data from the food of the Alto Paraíso inhabitants, comprising 39 households, were used as local urban food references (available in Rodrigues et al. 2016).

\subsection{Logistic regression}

Data obtained from the semi-structured questionnaires were categorized and analyzed using a multinomial logistic regression model to assess the relative influencing factors such as demographics, socioeconomics, and the isolation gradient of the local agro-food system. Conducting this multivariate discriminant analysis by household provides a good way of sorting data according to multiple influencing factors (Kleinbaum and Klein 2010), including the home community, government programs, market participation, and distance gradient. A similar analysis was carried out by Fisher and Lewin (2013) that applied a logistic regression to assess the association between socioeconomic conditions and public programs regarding food insecurity in rural Malawi.

Closed answers obtained through the questionnaire were categorized in binary format (i.e., 0 or 1). This allowed us to establish dependent variables related to the agro-food system and classify government aid, such as Bolsa Familia or financial family aid (FFA), pensions for disability or death (PEN), retirement (RET), and others (maternity aid or less expressive local aids such as Seguro Defeso, and among others), and the community's distance from towns (DIST, which are accessible and remote) as independent variables (i). The response variables (i.e., agro-food, diet, and subsistence resource use) were analyzed for all explanatory factors (i.e., sex, government aid, and community distance). We used a beta value $(\beta)$, standard error (SE), chi-square statistic $\left(\chi^{2}\right), p$ value of coefficients (B and intercept), and Nagelkerke pseudo-R-square $\left(R^{2}\right)$ and $p$ value of multinomial predictors in the model for each input variable. The variable selection in the logistic regression model was mainly fulfilled based on the non-collinearity premise in addition to participant observation in communities. This method of analysis is the most appropriate for bivariate data (Kleinbaum and Klein 2010). All statistical analyses (logistic and isotopic) were performed using the software $\mathrm{R}$ version 2.9.2 at a significance level of $p \leq 0.05$.

\section{Results and discussion}

\subsection{Socioeconomics}

Starting with socioeconomic conditions, there is a small difference in favor of more affordable groupings. Housing conditions were much higher in communities closer to urban centers. While $75.93 \%$ of dwelling of accessible communities 
were of brickwork and only $18.52 \%$ of mud brick (adobe), in the remote villages were $29.63 \%$ against $62.96 \%$ with the same dwelling conditions, respectively. Despite some equivalence, these communities still had slightly higher percentages of social assistance, with $70.37 \%$ of Family Financial aid (FFA) against $66.67 \%$ in remote villages and $14.81 \%$ and $3.7 \%$ of Pension (PEN) for the same areas, respectively. The average family monthly income ranged from $\mathrm{R} \$ 100$ to $\mathrm{R} \$ 400$, which reinforces the retirement weight in detriment to other sources due to low average revenue. Although corresponding to only one monthly minimum wage ( $\mathrm{R} \$ 800$ at the time), retirement and other types of benefits such as Bolsa Familia (on average, R\$300-400 per UD in the Kalunga) has a considerable local income impact by increasing purchasing power. Regarding formal education, the reported illiteracy level was very high, ranging from 60 to $80 \%$. The remaining percentage was primarily composed of individuals that had obtained partial elementary schooling.

\subsection{Subsistence agriculture, extractive practices, and food consumption}

Rice and beans are the staple food of the country (Barbosa 2007). Local food is generally comprised of traditional items such as rice and beans, followed by manioc flour (Table 1). Interview data revealed that these are indispensable daily food items. All communities consumed high quantities of rice and beans (Table 1). Though these items are consumed in high quantities (see Food items in Table 1), they are farmed at low rates in the accessible villages (see Crops grown in Table 1). Baiocchi (2006) suggested that cassava flour also plays a significant role as a staple and a cash crop; this information was confirmed by the high frequency of consumption as well as the high frequency of it being grown as crops by Kalunga households (Table 1).

Following cassava, pumpkin, and maize are the most common cultivated crops (Table 1). Maize is primarily used to feed pigs and chickens, which was evident from crosschecking consumption and production data (see Food items in Table 1). Maize cultivation in the remote communities was higher than in those more accessible communities (Table 1).

Farming is more restricted to self-consumption and subsistence; however, items such as cassava also are used as cash crops. In this regard, traditional crops grown such as beans, sweet potatoes, okra, jiló, sesame, and cassava were present in considerably higher percentages in remote groupings than in accessible communities (Table 1). Cassava flour, or "drug," as it is called in Kalunga, plays the most significant role in both farming and economy (Baiocchi 2006). This is evidenced by both production data and food consumption (Table 1). In this regard, Rogé et al. (2016) claimed that cassava had a proven track record of reducing hunger when used as a perennial staple crop.

In general, traditional items such as manioc and pumpkin were observed more often in remote communities than in those with direct influences from bordering towns (Table 1). However, in a nearby community called Limoeiro, there was a pronounced production of manioc flour due to PRONAF (the National Program for Strengthening Family Agriculture) investments. Animal breeding were restricted to cattle corrals, pigsties, and chicken coops, mainly directed toward subsistence self-consumption (see Food items in Table 1).

It is worth highlighting that the consumption of chicken, beef, and processed food items such as sausages and soft drinks were also more highly consumed in accessible areas (Table 1). Conversely, fish consumption had been more common in remote communities (Table 1). Although low, the consumption of fruit such as bananas and oranges was slightly higher in remote communities (Table 1). Extractive food practices were mainly related to fishing and, to a lesser extent, game meat derived from animals such as the paca (Cuniculus paca), tatu (armadillo, Dasypodidae family), agouti (Dasyprocta sp.), and wild pig (Tayassu pecari). These results did not officially appear in the table's data due the inhabitants fearing subsequent environmental inspection and criminal liability according to Article 29 of the Environmental Crimes Act (Law 9605/98). At the same time, the isotopic results revealed the consumption of such items mainly in remote villages, after more time in the Kalunga territory was possible to observe the consumption of game meat.

\subsection{Stable isotopes from local food and resources use}

Three clear groups were conspicuous in a plot of $\delta^{13} \mathrm{C}$ versus $\delta^{15} \mathrm{~N}$ (Fig. 2a). Regarding the dispersion of data, the records of the communities of Teresina de Goiás are the least dispersed (Fig. 2b), which indicates the greater homogeneity of food consumption and use of natural resources. Unexpectedly, despite being one of the regions most served by PRONAF and with greater cassava flour production, the increase in purchasing power provided by extra income and proximity to the city reinforces the process of agro-food transition. This isotopic result corresponds to the data of "subsistence agriculture, extractive practices, and food consumption," which showed more chicken, sausage, and soft drink consumption in the nearby communities of Teresina.

Overall, the average values of $\delta^{15} \mathrm{~N}$ and $\delta^{13} \mathrm{C}$ (Table 2) among the five remote villages expressed a greater food diversity with more consumption of game meat and fish, while the average values among the six accessible villages denoted a more homogenized diet with the presence of sugar and processed items. Rodrigues et al. (2016) found similar results to those of nearby Kalunga communities (Table 2) in rural 
Table 1 Percentage (\%) of items of food consumed and crops planted by household in the accessible and remote Kalunga communities, respectively

\begin{tabular}{|c|c|c|c|c|c|c|c|}
\hline \multirow[t]{2}{*}{ Food items } & \multicolumn{3}{|c|}{ Communities } & \multirow[t]{2}{*}{ Crops grown } & \multicolumn{3}{|c|}{ Communities } \\
\hline & Accessible & Remote & Total $(\%)$ & & Accessible & Remote & Total (\%) \\
\hline Rice & 93.94 & 92.59 & 93.26 & Manioc & 86.55 & 100 & 93.27 \\
\hline Bean & 90.91 & 96.3 & 93.60 & Rice & 29.62 & 62.96 & 46.29 \\
\hline Beef & 99.44 & 77.77 & 88.60 & Pumpkin & 62.96 & 62.96 & 62.96 \\
\hline Cassava Flour & 40.91 & 51.85 & 46.38 & Maize & 55.55 & 81.48 & 68.51 \\
\hline Chicken & 68.51 & 14.81 & 41.66 & Jiló & 42.59 & 45.68 & 44.13 \\
\hline Soda & 12.5 & 7.41 & 9.95 & Okra & 48.49 & 36.1 & 42.29 \\
\hline Pumpkin & 24.24 & 33.33 & 28.78 & Tomato & 10.09 & 20.68 & 15.38 \\
\hline Manioc & 4.55 & - & 2.27 & Bean & 35.18 & 51.85 & 43.51 \\
\hline Potato & 3.03 & - & 1.51 & Cane & 18.53 & 26.23 & 22.38 \\
\hline Beet & 6.06 & - & 3.03 & Carrot & 13.94 & 33.33 & 23.63 \\
\hline Carrot & 3.03 & 3.7 & 3.36 & Beet & 12.5 & - & 6.25 \\
\hline Sausage & 44.44 & 18.51 & 31.47 & Chuchu & 12.5 & - & 6.25 \\
\hline Soy & 3.03 & - & 1.51 & Cotton & 12.5 & - & 6.25 \\
\hline Pork & 24.07 & 3.7 & 13.88 & Cofee & 10.09 & - & 5.04 \\
\hline Tomato & 3.03 & 3.7 & 3.36 & Sweet potato & 14.95 & 52.08 & 33.51 \\
\hline Orange & 1.52 & 7.0 & 4.26 & Sesame & 9.25 & 18.51 & 13.88 \\
\hline Fish & 31.48 & 77.77 & 54.62 & Maxixe & 7.69 & 12.05 & 9.87 \\
\hline Banana & 3.03 & 7.41 & 5.22 & Yam & 20 & 16.66 & 18.33 \\
\hline Jiló & 1.52 & 7.41 & 4.46 & Tobacco & - & 16.66 & 8.33 \\
\hline Pasta & 3.03 & 11.11 & 7.07 & Urucum & 7.69 & 12.05 & 9.87 \\
\hline Natural Juice & - & 3.7 & 1.85 & Cucumber & 7.69 & 33.33 & 20.51 \\
\hline Okra & 4.55 & 3.7 & 4.12 & Capsicum & 7.69 & - & 3.84 \\
\hline Artificial juice & - & 7.41 & 3.70 & Aubergine & - & 25 & 12.5 \\
\hline Natural chicken & - & 3.7 & 1.85 & Potato & 11.11 & 48.14 & 29.62 \\
\hline Egg & 1.52 & 3.7 & 2.61 & - & - & - & \\
\hline Maxixe & 1.52 & - & 0.76 & - & - & - & \\
\hline Spices & 1.52 & - & 0.76 & - & - & - & \\
\hline
\end{tabular}

areas of Alto Paraíso de Goiás, which were $-16.7 \pm 0.97 \%$ o and $8.8 \pm 0.43 \%$ o to $\delta^{15} \mathrm{~N}$ and $\delta^{13} \mathrm{C}$, respectively. This also corresponds to the isotopic results of Reinaldo et al. (2015) with rural settings in northeastern Brazil. However, the same pattern does not apply to remote slave-remnant communities, which have shown a greater use of local subsistence resources and maintenance of traditional food habits.

Table 2 ANOVA results with the number of individuals sampled $(N)$, means and standard deviation of $\delta^{13} \mathrm{C}$ and $\delta^{15} \mathrm{~N}(\mu \pm \mathrm{SD})$ of fingernails of Kalunga communities (total, accessible, and remote) and Alto Paraíso $(\mathrm{GO})$ town residents. Different letters represent statistical significance at $(p<0.05)$

\begin{tabular}{llll}
\hline Community & $\delta^{13} \mathrm{C}$ & $\delta^{15} \mathrm{~N}$ & $\mathrm{~N}$ \\
\hline Alto Paraíso & $-16.99 \pm 1.07 \mathrm{a}$ & $9.38 \pm 0.39 \mathrm{a}$ & 38 \\
Kalunga total & $-18.67 \pm 1.29 \mathrm{~b}$ & $9.68 \pm 0.58 \mathrm{a}$ & 86 \\
Kalunga accessible & $-18.09 \pm 1.14 \mathrm{~b}$ & $9.42 \pm 0.38 \mathrm{a}$ & 54 \\
Kalunga remote & $-19.64 \pm 0.88 \mathrm{c}$ & $10.13 \pm 0.39 \mathrm{~b}$ & 32 \\
\hline
\end{tabular}

Although the average $\delta^{13} \mathrm{C}$ value in accessible settings significantly differed from that of the control group at Alto Paraíso (Table 2), we observed a gradual food transition toward the town (Fig. 2a). The difference between the control group and those in isolated settings was much more significant, especially regarding $\delta^{13} \mathrm{C}$ values (Table 2 ). The significant $\delta^{13} \mathrm{C}$ decrease in the accessible settings and control group (Table 2) is partly a result of the higher consumption of industrialized market items in these areas (Tables 2 and 4). Concerning the differences among $\delta{ }^{13} \mathrm{C}$ average values, the proportion of $\mathrm{C}_{4}$-based material found in the fingernails of individuals residing in remote Kalunga settings was around $43 \%$, but increased to around $54 \%$ according to samples from accessible villages and was as high as $61 \%$ for individuals in the town, according to the equation of $\% \mathrm{C}_{4}$-the dilution model of Fry (2006).

No significant difference was found among $\delta^{15} \mathrm{~N}$ values between people in accessible villages and Alto Paraíso (Table 2). The data distribution showed a trend of reduction for $\delta^{15} \mathrm{~N}$ values toward the town (Fig. 2a). There was a 
a

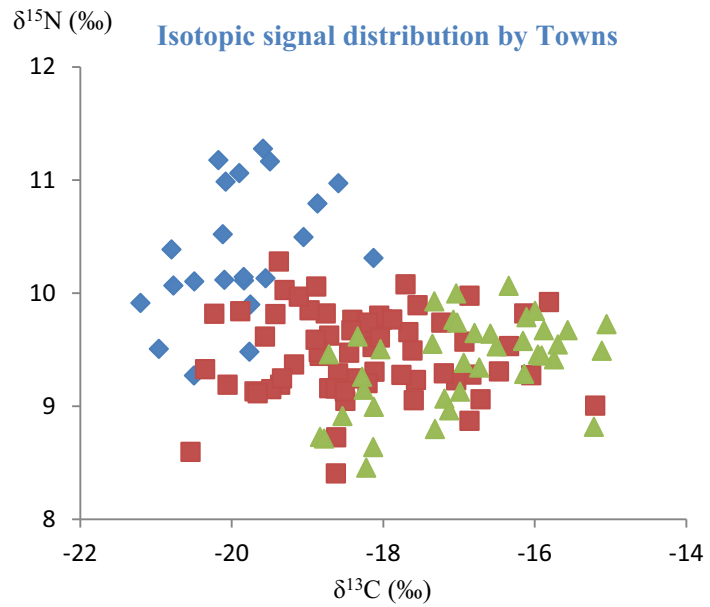

b
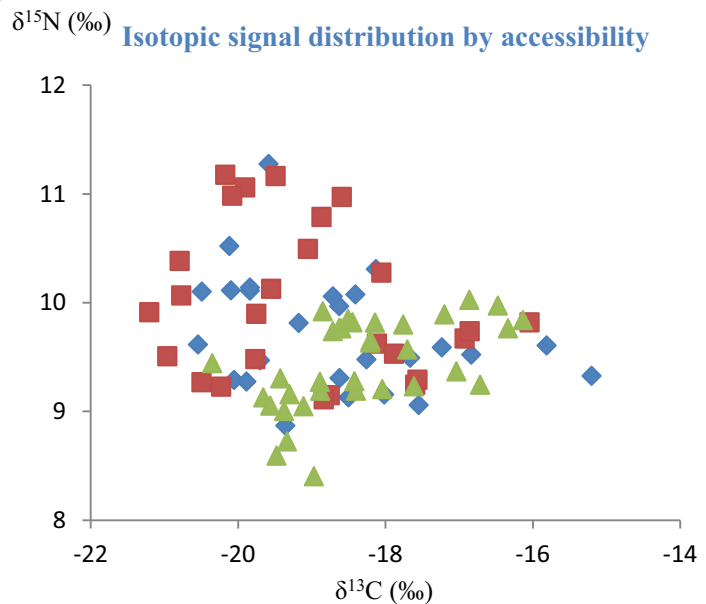

Fig. 2 a Nitrogen $\left(\delta^{15} \mathrm{~N}\right)$ and carbon $\left(\delta^{13} \mathrm{C}\right)$ isotopic values for the control group (Alto Paraíso- $\mathrm{GO}$ ) in green, accessible and remote communities (in red and blue, respectively), and $\mathbf{b}$ villages by neighboring municipality (Cavalcante in blue, Monte Alegre in red, and Teresina in green)

significant increase $(p<0.05)$ in $\delta^{15} \mathrm{~N}$ values from the town to the remote settings (Table 2 and Fig. 2a). This is possibly related to higher fish and game meat consumption in isolated areas. Conversely, there was a decrease in $\delta^{15} \mathrm{~N}$ values among accessible groups. This is possibly due to higher chicken consumption in these areas (Table 1).

The isotopic analysis results confirmed the existence of agro-food change in the rural communities of the Brazilian Cerrado (Fig. 2). There was a significant difference between the accessible communities, the most isolated villages, and urban areas (Table 2). This indicates that remote villages maintain a more traditional agro-food system involving fewer industrialized items and the use of more diverse natural resources (e.g., cassava, fish, game meat, rice, beans, and other foods derived from $\mathrm{C}_{3}$ plants).

The three main food items in Kalunga territory are cassava, rice, and beans. The $\delta^{13} \mathrm{C}$ value of cassava is around $-27 \%$, whereas rice and beans are $-28.2 \%$ and $-26.5 \%$, respectively (Nardoto et al. 2011). Significant differences in the $\delta^{13} \mathrm{C}$ values of these items can be explained by a series of factors, including higher meat consumption and sugar used in coffee, but especially an increased consumption of processed foods in those more accessible settings.

The high $\delta^{15} \mathrm{~N}$ and low $\delta^{13} \mathrm{C}$ values seen in those remote settings (Table 2) can be explained by the frequent consumption of game meat, freshwater fish, and $\mathrm{C}_{3}$ food items such as cassava, rice, and beans (see Nardoto et al. 2011). This trend occurs due to the natural accumulation of $\delta^{15} \mathrm{~N}$ through the food chain as a result of consuming these types of animal proteins, in addition to diets consisting mainly of natural local items with more negative $\delta^{13} \mathrm{C}$ values (a $\mathrm{C}_{3}$ source) (Nardoto et al. 2011). Isotopic analysis clearly revealed that the remote villages consumed higher amounts of game meat and/or fish despite the interviews having indicated that hunting was rare (the lack of entries for this item was later explained to be a result of inhabitants fearing subsequent environmental inspection).

Concerning isotopic values of remote settings (Table 2), De Lima et al. (2018) found similar results with residents of the Amanã Sustainable Development Reserve (SDR), located in the middle Solimões region. According to De Lima et al. (2018), the isotopic averages of $\delta^{15} \mathrm{~N}$ and $\delta^{13} \mathrm{C}$ were $11.6 \pm$ $0.6 \%$ and $-22.9 \pm 1.1 \%$ o, expressing a very complex web food with huge intakes of fish, game meat, and more items derived from $\mathrm{C}_{3}$ plants. In addition to all livelihood biocultural factors, the slight difference regarding remote Kalunga settings can be explained by lower fish and game meat availability in the Cerrado region than in the Amazon.

The gradual increase of $\delta^{13} \mathrm{C}$ values toward the urban area (Fig. 2a) is strong evidence of agro-food transition. Similar control group results were found in Piracicaba, São Paulo, where the $\delta^{13} \mathrm{C}$ and $\delta^{15} \mathrm{~N}$ values of fingernail samples were $-16.5 \%$ and $9.3 \%$, respectively (Gragnani et al. 2013). Other agro-food transition evidence involved the absence of isotopic differences $\left(\delta^{15} \mathrm{~N}\right.$ values) between accessible communities and the control group (Table 2). The decreasing trend of $\delta^{15} \mathrm{~N}$ values toward town (Fig. 2a) indicates that food becomes more simplified as communities approach the urban area. That is, there are fewer food chain links and less game, fish, vegetables, and locally based items overall (Lee-Thorp and Sponheimer 2006; Nardoto et al. 2011).

The higher $\delta^{13} \mathrm{C}$ values of accessible settings (Table 2) reflect the daily presence of socioeconomic development and supermarket products. Foods have therefore shifted from $\mathrm{C}_{3}$ to $\mathrm{C}_{4}$ sources. This pattern indicates an increasingly homogenized diet (Rodrigues et al. 2016), which stands in contrast to the national food base that is more typically derived from $\mathrm{C}_{3}$ plants, including rice, beans, cassava flour, fish, and game. 
Studies report that these foods are also being replaced with processed items among the riverine communities of the Amazon (Nardoto et al. 2011; Piperata et al. 2011) and rural villages in the Cerrado (Rodrigues et al. 2016). These surveys also revealed a gradual increase in the consumption of items such as sugar, red meat, and chicken due to increased access to urban areas and retail products.

Therefore, these results confirm the initial hypothesis of increasing in $\delta^{13} \mathrm{C}$ values and decreasing in $\delta^{15} \mathrm{~N}$ as one moves toward town, supporting the findings of Nardoto et al. (2011), Reinaldo et al. (2015), and Rodrigues et al. (2016), which indicate more simplified food patterns from the point of view of the diversity of items and low-quality processed products. Notably, there were no statistical isotopic differences between genders regarding $\delta^{13} \mathrm{C}$ and $\delta^{15} \mathrm{~N}(-18.6$ and $-18.8 / 9.6$ and 9.8) for women and men, respectively. This result denotes that men eat slightly more processed items and red meat than women.

The consumption of $\mathrm{C}_{4}$-based foods is associated with higher levels of sugar and processed food, which reinforces the problems of food transition. This pattern can alter traditional livelihood practices in rural areas through its modifications of local agro-food systems. Some researchers argue that such rural dependence on the market economy and the consumption of external items increases the transition from locally based production to a reliance on processed foods (Padoch et al. 2008; Piperata et al. 2011). However, some variables will influence this transition at different rates depending on the context, since there are issues beyond the economic (Bleil 1998).

\subsection{Multinomial logistic regression analysis: the influencing factors on agro-food transition}

There was a decrease in food production related to selfconsumption in communities that received government assistance through retirement, Bolsa Familia, and pensions (Table 3). The increased income from retirement benefits resulted in a significant effect on food and natural resource use in Kalunga villages, specifically on cattle breeding and bean crops (Table 3). The traditional items such as beans (Vigna unguiculata - cowpea) and livestock (cattle) was seen at significantly lower rates in settings with retired beneficiaries (Table 3).

Lemon production was significantly lower in villages receiving the Bolsa Familia (Table 3). We also identified a significant influence on the consumption of processed items (i.e., frozen and canned foods, and beverages), beef, pork, sausages, and chicken (Table 3 ) from the proximity to towns. Industrialized food items, particularly frozen chicken, were consumed in significantly lower quantities in more isolated villages (Table 3 ).

Production diversification was also affected. Distance was a significant factor in the most isolated communities regarding the increased production of items such as potatoes, native fruits, and vegetables (Table 3). This relationship was even more evident for traditional items such as rice, maize, and fish, which were more abundant in remote settings (Table 3 ). Rice production was significantly lower $(<33 \%)$ in more accessible communities (Table 3 ). Although there was a difference in rice production between communities (see Crops grown in Table 1), consumption levels remained proportional (Food items in Table 1).

The pattern of pork consumption was inversely proportional to that of fish, higher in accessible settings (Table 3). This was also observed for beef consumption, $16 \%$ higher in more accessible communities, while the presence of livestock (cattle) was significantly higher in remote communities (Table 3 ). This suggests that the beef being consumed in accessible communities comes from outside the region. Moreover, cattle ranching was lower in villages benefiting from retirement (Table 3). The negative beta $(\beta)$ value denotes the relationship trend between variables. In this case, cattle ranching decreased in villages with retirement benefits. Given these results, the factors of distance and retirement benefits were significant, and should be considered when explaining differences in cattle ranching practices among the Kalunga.

There were also significant decreases in maize production among villages that benefited from pensions, even when factoring in distance (Table 3). While maize production declined closer to town, communities receiving pensions had $47 \%$ lower production (Table 3). This indicates a greater impact of the direct income transfer on self-consumption crops. Easier access to urban areas is clearly the main influencing factor behind the transition process involved in livelihood practices.

Likewise, De Bon et al. (2010) emphasize that the differences between rural and urban households appear to be decreasing with regard to livelihood practices. Under these circumstances, it is noted that some factors have greater influences on the local agro-food system than others (Table 3). Significant changes were observed despite the relative stability of the food tripod (rice, beans, and manioc flour) in accessible communities.

Among the many factors listed in Table 3, the presence of frozen chicken was remarkable. Outside of the lack of contribution to local value, the consumption of outside foodstuffs can generate the risk of contracting both globalized diseases (Piperata et al. 2011) and food poisoning due to the transportation and storage conditions in rural areas (Nardoto et al. 2011).

There are factors that may explain the significant decrease in fish consumption in accessible settings. However, it is more likely that this pattern is a result of the transition process; fish consumption was much higher in remote areas (Tables 2 and 4). This pattern may also be a result of the large number of rivers and tributaries that enter Kalunga territory, thereby making fish a strategic item for adaptive adjustment to remote conditions (Murrieta and Dufour 2004). The higher rate of 
Table 3 Multinomial regression analysis as percentage of negative (0) and positive answers (1) of independent variables (Indep), DIST (accessible and remote communities), FFA (Bolsa-Família), RET (retirement aid), and PEN (Pension aid) to agro-food dependent variables (Dep) with: a beta value of the logit model $(\beta)$, standard error
(SE), chi-square $\left(\chi^{2}\right)$ probability $(p)$, Nagelkerke value $\left(R^{2}\right)$, and predictive model probability $(p)$. Additionally, to DIST, $(0)$ represents accessible and (1) remote communities while to other variables (FFA, RET, and PEN) it is the agro-food item percentage (\%) in communities without (0) and with (1) those government programs

\begin{tabular}{|c|c|c|c|c|c|c|c|c|}
\hline \multicolumn{2}{|l|}{ Variables } & \multirow[t]{2}{*}{$\%(0)(1)$} & \multirow[t]{2}{*}{ B } & \multirow[t]{2}{*}{$\mathrm{SE}$} & \multirow[t]{2}{*}{$\chi^{2}$} & \multirow[t]{2}{*}{$p$} & \multirow[t]{2}{*}{$R^{2}$} & \multirow[t]{2}{*}{$P$} \\
\hline Dep. & Indep. & & & & & & & \\
\hline \multirow[t]{4}{*}{ Potato } & DIST & (11) (48) & 2.005 & 0.593 & 11.431 & $<0.01$ & 0.254 & $<0.01$ \\
\hline & FFA & $(20)(25)$ & 0.786 & 0.725 & 1.172 & 0.278 & & \\
\hline & RET & $(22)(27)$ & 0.699 & 0.677 & 1.065 & 0.301 & & \\
\hline & PEN & (25) (11) & -0.752 & 1.245 & 0.364 & 0.545 & & \\
\hline \multirow[t]{4}{*}{ Rice } & DIST & (30) (63) & 1.335 & 0.503 & 7.038 & $<0.01$ & 0.143 & 0.058 \\
\hline & FFA & (44) (39) & -0.026 & 0.594 & 0.001 & 0.965 & & \\
\hline & RET & (39) (43) & 0.205 & 0.570 & 0.129 & 0.718 & & \\
\hline & PEN & (43) (22) & -0.689 & 0.877 & 0.616 & 0.432 & & \\
\hline \multirow[t]{4}{*}{ Maize } & DIST & $(55)(81)$ & 1.149 & 0.600 & 3.667 & 0.055 & 0.208 & $<0.01$ \\
\hline & FFA & $(72)(61)$ & -0.842 & 0.672 & 1.570 & 0.210 & & \\
\hline & RET & (67) (60) & -0.686 & 0.622 & 1.216 & 0.270 & & \\
\hline & PEN & (69) (22) & -1.794 & 0.860 & 4.347 & 0.037 & & \\
\hline \multirow[t]{4}{*}{ Bean } & DIST & $(35)(52)$ & 0.772 & 0.504 & 2.347 & 0.125 & 0.107 & 0.149 \\
\hline & FFA & (36) (43) & -0.252 & 0.602 & 0.175 & 0.675 & & \\
\hline & RET & (49) (27) & -1.139 & 0.585 & 3.794 & 0.051 & & \\
\hline & PEN & (40) (44) & 0.500 & 0.753 & 0.442 & 0.506 & & \\
\hline \multirow[t]{4}{*}{ Banana } & DIST & $(65)(85)$ & 1.235 & 0.627 & 3.869 & 0.049 & 0.112 & 0.157 \\
\hline & FFA & $(76)(70)$ & -0.813 & 0.697 & 1.359 & 0.243 & & \\
\hline & RET & (74) (67) & -0.831 & 0.635 & 1.710 & 0.190 & & \\
\hline & PEN & (71) (77) & 0.778 & 0.879 & 0.784 & 0.375 & & \\
\hline \multirow[t]{4}{*}{ Lemon } & DIST & (46) (48) & 0.042 & 0.514 & 0.006 & 0.934 & 0.148 & 0.048 \\
\hline & FFA & $(60)(41)$ & -1.738 & 0.706 & 6.051 & 0.013 & & \\
\hline & RET & $(53)(36)$ & -1.626 & 0.683 & 5.659 & 0.017 & & \\
\hline & PEN & (47) (44) & 0.178 & 0.802 & 0.049 & 0.823 & & \\
\hline \multirow[t]{4}{*}{ Cattle } & DIST & (33) (67) & 1.414 & 0.536 & 6.943 & 0.008 & 0.220 & $<0.01$ \\
\hline & FFA & (44) (45) & -0.614 & 0.648 & 0.896 & 0.343 & & \\
\hline & RET & $(53)(30)$ & -1.373 & 0.631 & 4.726 & 0.029 & & \\
\hline & PEN & (47) (22) & -0.724 & 0.870 & 0.692 & 0.405 & & \\
\hline \multirow[t]{4}{*}{ Fishery } & DIST & (31) (77) & 2.021 & 0.555 & 13.227 & $<0.01$ & 0.246 & $<0.01$ \\
\hline & FFA & (48) (46) & -0.175 & 0.630 & 0.077 & 0.780 & & \\
\hline & RET & (49) (43) & -0.363 & 0.601 & 0.366 & 0.545 & & \\
\hline & PEN & (49) (33) & -0.142 & 0.794 & 0.032 & 0.857 & & \\
\hline \multirow[t]{4}{*}{ Native Fruits } & DIST & (57) (85) & 1.431 & 0.614 & 5.428 & 0.019 & 0.119 & 0.121 \\
\hline & FFA & (68) (66) & -0.240 & 0.635 & 0.142 & 0.705 & & \\
\hline & RET & (69) (63) & -0.370 & 0.597 & 0.385 & 0.534 & & \\
\hline & PEN & $(68)(55)$ & -0.205 & 0.740 & 0.077 & 0.781 & & \\
\hline \multirow[t]{4}{*}{ Vegetable garden } & DIST & (35) (70) & 1.712 & 0.536 & 10.169 & $<0.01$ & 0.205 & $<0.01$ \\
\hline & FFA & $(40)(50)$ & 0.607 & 0.608 & 0.996 & 0.318 & & \\
\hline & RET & (47) (46) & 0.228 & 0.581 & 0.155 & 0.693 & & \\
\hline & PEN & (44) (67) & 1.367 & 0.791 & 2.985 & 0.083 & & \\
\hline \multirow[t]{4}{*}{ Processed foods } & DIST & $(78)(52)$ & 1.158 & 0.513 & 5.094 & 0.024 & 0.094 & 0.231 \\
\hline & FFA & $(68)(70)$ & 0.069 & 0.610 & 0.012 & 0.909 & & \\
\hline & RET & (69) (70) & 0.092 & 0.587 & 0.024 & 0.875 & & \\
\hline & PEN & $(68)(78)$ & 0.170 & 0.874 & 0.038 & 0.845 & & \\
\hline
\end{tabular}


Table 3 (continued)

\begin{tabular}{|c|c|c|c|c|c|c|c|c|}
\hline \multicolumn{2}{|l|}{ Variables } & \multirow[t]{2}{*}{$\%(0)(1)$} & \multirow[t]{2}{*}{ B } & \multirow[t]{2}{*}{$\mathrm{SE}$} & \multirow[t]{2}{*}{$\chi^{2}$} & \multirow[t]{2}{*}{$p$} & \multirow[t]{2}{*}{$R^{2}$} & \multirow[t]{2}{*}{$P$} \\
\hline Dep. & Indep. & & & & & & & \\
\hline \multirow[t]{4}{*}{ Vegetables } & DIST & $(80)(44)$ & -1.510 & 0.520 & 8.421 & 0.003 & 0.181 & 0.023 \\
\hline & FFA & $(68)(67)$ & -0.074 & 0.635 & 0.013 & 0.906 & & \\
\hline & RET & $(67)(70)$ & 0.096 & 0.610 & 0.024 & 0.874 & & \\
\hline & PEN & $(65)(88)$ & 1.096 & 1.131 & 0.938 & 0.332 & & \\
\hline \multirow[t]{4}{*}{ Beef } & DIST & (94) (77) & -1.420 & 0.767 & 3.422 & 0.064 & 0.172 & 0.118 \\
\hline & FFA & (88) (89) & 0.433 & 0.894 & 0.235 & 0.627 & & \\
\hline & RET & $(86)(93)$ & 0.972 & 0.966 & 1.012 & 0.314 & & \\
\hline & PEN & $(87)(100)$ & 15.974 & 0.894 & 0.00 & 0.994 & & \\
\hline \multirow[t]{4}{*}{ Pork } & DIST & $(24)(04)$ & -2.199 & 1.108 & 3.936 & 0.047 & 0.214 & 0.024 \\
\hline & FFA & $(28)(12)$ & -1.543 & 0.826 & 3.493 & 0.061 & & \\
\hline & RET & (16) (20) & -0.551 & 0.818 & 0.454 & 0.500 & & \\
\hline & PEN & $(15)(33)$ & 0.887 & 0.856 & 1.073 & 0.300 & & \\
\hline \multirow[t]{4}{*}{ Sausages } & DIST & (44) (18) & -1.390 & 0.579 & 5.764 & 0.016 & 0.140 & 0.067 \\
\hline & FFA & $(40)(34)$ & 0.039 & 0.626 & 0.003 & 0.950 & & \\
\hline & RET & $(31)(43)$ & 0.608 & 0.595 & 1.046 & 0.306 & & \\
\hline & PEN & $(37)(22)$ & -1.115 & 0.865 & 1.664 & 0.197 & & \\
\hline \multirow[t]{4}{*}{ Chicken } & DIST & $(68)(15)$ & -2.584 & 0.627 & 16.966 & $<0.01$ & 0.330 & $<0.01$ \\
\hline & FFA & $(48)(52)$ & 0.333 & 0.666 & 0.250 & 0.617 & & \\
\hline & RET & (49) (53) & 0.409 & 0.635 & 0.414 & 0.520 & & \\
\hline & PEN & $(50)(55)$ & -0.424 & 0.771 & 0.302 & 0.582 & & \\
\hline
\end{tabular}

fish consumption in the most isolated communities may also be a factor in the switch to pork in these more accessible localities, which runs contrary to the historically minor consumption of pork in the country's backlands (Carneiro 2003).

The higher rate of pork consumption in accessible villages can also be explained by relatively easy access to supermarkets and the prestige inherent to red meat according to Western food standards (Bleil 1998). This evidence was also relevant for the higher rate of beef consumption seen in the accessible communities (Table 1), although the presence of cattle was significantly lower in these areas than in the more isolated communities (Table 3).

The practice of purchasing foods at supermarkets in neighboring towns seems to be a recent one. This coincides with the advent of government policies such as retirement, pension, Bolsa Familia, among others. It is worth mentioning that there is a higher percentage of families receiving these government subsidies in the most accessible areas (Tables 1 and 3). This may be an important influencing factor behind the changes in food habits and livelihood. In regard to cash transfer programs, Piperata et al. (2016) point out that recipient households' food security was measurably worse off and children's poor nutritional status was practically unchanged 4 years into the Bolsa Familia aid program.

Regarding the effects of conditional cash transfer on the food transition in the Amazon, Piperata et al. (2016) argue that the dietary health of rural residents deteriorated after the implementation of Bolsa Familia due to the decline in social cooperation, the abandonment of cassava fields, and new aspirations of the younger generation. Their results correspond with those found here. Besides the influence of conditional cash transfers on the reduction of crop farming (see Table 3), the question of the new aspirations of Kalunga young people is also accurate. The Kalunga territory is experiencing an exodus of young people from the remote areas toward more accessible and urban settings.

While retirement may have allowed the elderly and their relatives to remain in remote settings, the extra income may have discouraged the production and consumption of traditional items such as beans, lemon, and cattle (Table 3). These items were seen at significantly lower rates in communities containing retirees. The interference of greater purchasing power may be a significant factor influencing the replacement of local foods with processed items. Conversely, the decrease of local foods can also be explained by the natural reduction of the elderly labor force in subsistence farming.

However, contrary to the supposed reduction of the elderly labor load, it was common to find in remote settings several family members who depend exclusively on the retiree's salary. In addition to supplying a domestic unit for the family, it was observed that the retiree's income also benefits other relatives, enhancing purchasing power on the one hand but increasing a 
dependency on the retiree's salary by some family members on the other hand. However, a more detailed investigation through an ethnographic study might be necessary to understand the influence of retirement on rural livelihoods. Another reinforcement of this observation was the lower rate of lemon and maize production seen in communities with Bolsa Familia and pensions. Although the variables of distance and retirement influence the production of these items, the effect of Bolsa Familia was statistically more significant (Table 3).

While not a criticism of retirement benefits, since they are an unquestionable right, it is likely that such public subsidies are disconnecting people from traditional production methods. In a study involving riverine people, Piperata et al. (2011) argue that the factor most likely contributing to the replacement of local produce with processed foods was the extra income received from the Bolsa Familia. Sharaunga and Wale (2013) assume that agricultural policies and food aid can create both incentives and disincentives to local subsistence production. They also argue that these policies create a sustained dependence pattern involving external goods that undermines local food production incentives. Hawkes (2005) points out that external investments (both public and private) have been key mechanisms stimulating the consumption of highly processed foods in developing countries. Thus, simple cash transfers provided by direct assistance policies can impact daily subsistence activities by discouraging individual efforts and technical improvements in the field. Veiga (2001) proposed the idea that the federal government should participate in rural development on a contractual basis instead of restricting its aid to the direct transfer of funds. Providing alternative ways to generate income may be an option for the strategic development of rural regions.

There are robust opportunities for the Kalunga to generate income through traditional knowledge, but these methods should remain an extension of their daily endogenous activities (Baiocchi 2006). PRONAF was a well-targeted public policy implemented in the Kalunga territory that involved the construction of "casas de farinha" in accessible communities to allow the maintenance of food customs and the improvement of local socioeconomic conditions. Despite the three primary foods (i.e., rice, beans, and manioc flour) having remained in both accessible and isolated communities, the agro-food transition signals are varied and should not be underestimated. Economic transformations resulting from greater access to retirement, pensions, and the Bolsa Familia have intensified the food transition process while reducing subsistence production; these results match those of other similar studies (Nardoto et al. 2011; Piperata et al. 2011; Rodrigues et al. 2016).

We therefore highlight that rural communities may in fact be undergoing an agro-food transition process that is moving toward urban settings. Since adjustments to changes may take time to become effective, reorganization will require a communal awareness of the impacts of agro-food transition and the proactive decision-making of stakeholders, most importantly those of local actors and government representatives.

Another issue not addressed here concerns about a possible effect of tourism on agro-food systems. The most organized communities for tourism and which receive the largest visitors flow are those closest to the urban centers, especially those located in Cavalcante and Teresina. Therefore, the effect of tourism on local food is much correlated with the effect of distance (DIST) from towns. Thus, it is emphasized that this variable was not part of this study object, precisely due its dependence regarding distance and socioeconomic development process. However, a good question for future studies would be extracting its effect.

\section{Conclusion}

This is the first time that an approach involved a multinomial discriminant model was used jointly with stable isotopes to assess the impacts of the socioeconomic development process on agro-food systems in rural communities. This interdisciplinary procedure enabled the identification of multiple factors influencing the agro-food transition process in rural villages and revealed a pattern change involving a shift from the consumption of wild/native items to processed foodstuffs approaching urban areas. Beyond food security, we raised questions concerning the impact of modern lifestyles on remote rural settings and the consequences they pose for traditional livelihood. Finally, urban access and the way in which government subsidies have been implemented in rural areaswithout social participation and taking into account local sociocultural dispositions - has impacted local livelihoods, compromising the re-elaboration of food habits and traditional farming.

Acknowledgments We thank the communities studied for their patience and kindness in providing information so important for this article, and the Foundation Research Support of the State of São Paulo (FAPESP), which enabled the development of this work.

Funding This study was funded by FAPESP (grant number 11/08686-3).

\section{Compliance with ethical standards}

Conflict of interest The authors declare that they have no conflicts of interest.

\section{References}

Baiocchi MN (2006) Kalunga: Povo da Terra. Goiânia: Edufg/Cegraf Barbosa L (2007) Feijão com arroz e arroz com feijão: o Brasil no prato dos brasileiros. Horizontes Antropológicos 13(28):87-116

Bleil SI (1998) O Padrão Alimentar Ocidental: Considerações sobre a mudança de hábitos no Brasil. Cadernos de Debate 6:1-25 
Carneiro H (2003) Comida e Sociedade: uma história da alimentação. Campus, Rio de Janeiro

De Bon H, Parrot L, Moustier P (2010) Sustainable urban agriculture in developing countries. A review. Agron Sustain Dev 30:21-32. https://doi.org/10.1051/agro:2008062

De Lima AC, Brondízio E, Nardoto GB, Nascimento ACS (2018) Conditional cash transfers in the Amazon: from the nutrition transition to complex dietary behavior change. Hum Ecol xx:xx-xx. (no press)

Farquhar GD, Ehleringer JR, Hubick KT (1989) Carbon isotope discrimination and photosynthesis. Annu Rev Plant Physiol Plant Mol Biol 40:503-537. https://doi.org/10.1146/annurev.pp.40.060189.002443

Fisher M, Lewin PA (2013) Household, community, and policy determinants of food insecurity in rural Malawi. Dev South Afr 30(4-05): 451-467. https://doi.org/10.1080/0376835X.2013.830966

Fry B (2006) Stable isotope ecology. Springer Science+Business Media, New York

Gragnani JG, Garavello MEPE, Silva RJ, Nardoto GB, Martinelli LA (2013) Can stable isotope analysis reveal dietary differences among groups with distinct income levels in the city of Piracicaba (southeast region, Brazil)? J Hum Nutr Diet 10:1-7. https://doi.org/10. $1111 / \mathrm{jhn} .12148$

Hawkes C (2005) The role of foreign direct investment in the nutrition transition. Public Health Nutr 8(4):357-365. https://doi.org/10. 1079/PHN2004706

Huelsemann F, Flenker U, Koehler K, Schaenzer W (2009) Effect of a controlled dietary change on carbon and nitrogen stable isotope ratios of human hair. Rapid Commun Mass Spectrom Malden 23: 2448-2454. https://doi.org/10.1002/rcm.4039

Kleinbaum DG, Klein M (2010) Logistic regression: a self-learning text. Springer-Verlag, New York

Lee-Thorp J, Sponheimer M (2006) Contributions of biogeochemistry to understanding hominin dietary ecology. Yearb Phys Anthropol 49: 131-148. https://doi.org/10.1002/ajpa.20519

Mittermeier R et al (2004) Hotspots revisited: Earth's biologically richest and Most endangered terrestrial ecoregions. The University of Chicago Press, Chicago

Murrieta RSS, Dufour DL (2004) Fish and Farinha: protein and energy consumption in Amazonian rural communities on Ituqui Island, Brazil. Ecol Food Nutr 4:231-255. https://doi.org/10.1080/ 03670240490447550

Nardoto GB, Silva S, Kendall C, Ehleringer JR, Chesson LA, Ferraz ESB, Moreira MZ, Ometto JPHB, Martinelli LA (2006) Documenting geographical patterns of human diet through stable isotope analysis of fingernails. Am J Phys Anthropol 131:137146. https://doi.org/10.1002/ajpa.20409

Nardoto GB, Murrieta RSS, Prates LEG, Adams C, Garavello MEPE, Schor T, de Moraes A, Rinaldi FD, Gragnani JG, Moura EAF, Duarte-Neto PJ, Martinelli LA (2011) Frozen chicken for wild fish: nutritional transition in the Brazilian Amazon region determined by carbon and nitrogen stable isotope ratios in fingernails. Am J Hum Biol 23:642-650. https://doi.org/10.1002/ajhb.21192
O’Connell TC, Hedges REM, Healey MA, Simpson AHRW (2001) Isotopic comparison of hair, nail and bone: modern analyses. $\mathrm{J}$ Archaeol Sci 28:1247-1255. https://doi.org/10.1006/jasc.2001. 0698

Oliveira AC, Soares MGM, Martinelli LA, Moreira MZ (2006) Carbon sources of fish in an Amazonian floodplain lake. Aquat Sci 68:229 238. https://doi.org/10.1007/s00027-006-0808-7

Padoch CE, Brondizio E, Costa S, Pinedo-Vasquez M, Sears RR, Siqueira A (2008) Urban forest and rural cities: multi-sited households, consumption patterns, and forest resources in Amazonia. Ecol Soc 13(2):2. https://doi.org/10.5751/ES-02526-130202

Piperata BA, Spence JE, Gloria P, Hubbe M (2011) The nutrition transition in Amazonia: rapid economic change and its impact on growth and development in Ribeirinhos. Am J Phys Anthropol 146:1-13. https://doi.org/10.1002/ajpa.21459

Piperata BA, McSweeney K, Murrieta RS (2016) Conditional cash transfers, food security, and health: biocultural insights for povertyalleviation policy from the Brazilian Amazon. Curr Anthropol 57(6):806-826. https://doi.org/10.1086/688912

Popkin BM (2006) Global nutrition dynamics: the world is shifting rapidly toward a diet linked with non-communicable diseases. Am J Clin Nutr 84:289-298. https://doi.org/10.1093/ajcn/84.1.289

Reinaldo EDF, Da Silva MRF, Nardoto GB et al (2015) Mudanças de hábitos alimentares em comunidades rurais do semiárido da região nordeste do Brasil. Interciencia 40(5):330-336

Rodrigues LPF, Carvalho RC, Maciel A, Otanasio PN, Garavello MEPE, Nardoto GB (2016) Food insecurity in urban and rural areas in Central Brazil: transition from locally produced foods to processed items. Ecol Food Nutr 55(4):365-377. https://doi.org/10.1080/ 03670244.2016.1188090

Rogé P, Snapp S, Kakwera MN, Mungai L, Jambo I, Peter B (2016) Ratooning and perennial staple crops in Malawi. A review. Agron Sustain Dev 36:50. https://doi.org/10.1007/s13593-016-0384-8

Schor T, Azenha GS (2017) Ribeirinho food regimes, socioeconomic inclusion and unsustainable development of the Amazonian floodplain. EchoGéo 41:1-14. https://doi.org/10.4000/echogeo.15052

Sharaunga S, Wale E (2013) The dis-incentive effects of food aid and agricultural policies on local land allocation in developing countries: the case of Malawi. Dev Southern Africa, Pretoria, Ithaca, v 30(5): 491-507. https://doi.org/10.1080/0376835X.2013.817300

Veiga JE (2001) O Brasil rural ainda não encontrou seu eixo de desenvolvimento. Estudos Avançados 15(43):101-119. https://doi. org/10.1590/S0103-40142001000300010

Publisher's Note Springer Nature remains neutral with regard to jurisdictional claims in published maps and institutional affiliations. 